\title{
The Effect of Morinda citrifolia and Arthrospira plattensis Powder on the Performance and Quality of Broiler Duck Carcasses
}

\author{
Kurniawan $\mathrm{D}^{1}$, Christie CDY² \\ ${ }^{1}$ Department of Animal Science, Faculty of Animal Sience, University of Kahuripan Kediri \\ ${ }^{2}$ Department of Agrotechnology, Faculty of Agriculture, University of Kahuripan Kediri \\ Jl. Pelem No 1 Pare Kediri Indonesia \\ E-mail: davidkurniawan34@yahoo.co.id
}

(received 01-10-2019; revised 17-01-2020; accepted 12-02-2020)

\begin{abstract}
ABSTRAK
Kurniawan D, Christie CDY. 2020. Pengaruh pemberian tepung Morinda citrifolia dan Arthrospira plattensis terhadap kinerja dan kualitas karkas itik pedaging. JITV 25(1):40-44. DOI: http://dx.doi.org/10.14334/jitv.v25i1.2053.

Penelitian ini bertujuan mengetahui kinerja dan kualitas karkas itik pedaging yang diberi tepung Morinda citrifolia dan Arthospira platensis. Sebanyak 168 ekor itik pedaging (unsexed) yang berumur 2 minggu dengan rata-rata bobot badan $463 \pm$ 29,38 g dan tingkat keragaman 6,35\%, dikelompokkan ke dalam 28 petak masing-masing berisi 6 ekor. Metode penelitian yang digunakan adalah uji biologis yang dirancang dengan rancangan acak lengkap (RAL) yang terdiri dari 7 perlakuan dan 4 ulangan yaitu T0 (pakan basal sebagai kontrol), T1 (pakan basal $+0,2 \%$ of Morinda citrifolia powder (MP)), T2 (pakan basal $+0,5 \%$ of Arthrospira plattensis powder (AP)), T3 (pakan basal $+0,2 \%$ of MP+ 0,5\% of AP), T4 (pakan basal $+0,4 \%$ of MP $+0,5 \%$ of AP), T5 (pakan basal $+0,2 \%$ of MP $+0,1 \%$ of AP), T6 (pakan basal $0,4 \%$ of MP $+0.1 \%$ of AP). Parameter yang diuji adalah konsumsi pakan, pertambahan bobot badan, konversi pakan, persentase karkas, lemak abdominal dan organ dalam. Data yang diperoleh dianalisa menggunakan analisa ragam ANOVA, apabila terdapat perbedaan dilanjutkan dengan uji jarak berganda Duncan's. Hasil penelitian menunjukkan bahwa perlakuan tidak berpengaruh nyata $(\mathrm{P}>0.05)$ terhadap konsumsi pakan, pertambahan bobot badan dan konversi pakan. Perlakuan juga tidak berpengaruh nyata $(P>0.05)$ terhadap persentase karkas, lemak abdominal dan organ dalam. Pemberian pakan dengan tepung Morinda citrifolia dan Arthospira platensis tidak dapat meningkatkan produktifitas dan kualitas karkas itik pedaging.
\end{abstract}

Kata Kunci: Itik Pedaging, Kinerja, Kualitas Karkas

ABSTRACT

Kurniawan D, Christie CDY. 2020. The effect of Morinda citrifolia and Arthrospira plattensis Powder on Performance and Quality of Broiler Duck Carcasses. JITV 25(1):40-44. DOI: http://dx.doi.org/10.14334/jitv.v25i1.2053.

This study was aimed to investigate performance and quality of broiler duck carcasses fed with Morinda citrifolia and Arthrospira plattensis. A total of 168 two-week-old broiler duck with an initial average body weight of $463 \pm 29.38 \mathrm{~g}$ and a diversity of $6.35 \%$ were randomly allotted to 7 experimental groups with 4 replications each with 6 bird per replication. Treatments were T0 (basal diet as a control), T1 (basal diet $+0.2 \%$ of Morinda citrifolia powder (MP)), T2 (basal diet $+0.5 \%$ of Arthrospira plattensis powde(AP)), T3 (basal diet $+0.2 \%$ of MP+ $0.5 \%$ of AP), T4 (basal diet $+0.4 \%$ of MP $+0.5 \%$ of AP), T5 (basal diet $+0.2 \%$ of MP $+0.1 \%$ of AP), T6 (basal diet $0.4 \%$ of MP $+0.1 \%$ of AP). Variables measured were feed intake, body weight gain, feed conversion ratio, carcass percentage, abdominal fat, and visceral organ. Data were analyzed for variance based on a Completely Randomize Design and continued with Duncan's multiple Range Test for differences. Result showed that the treatments did not affect $(\mathrm{P}>0.05)$ on feed intake, body weight gain and feed conversion ratio. The treatments also did not affect $(\mathrm{P}>0.05)$ carcass percentage, abdominal fat, and visceral organ. The diet did not significantly improve performance and quality of broiler duck carcasses.

Key Words: Broiler Ducks, Performance, Carcass Quality

\section{INTRODUCTION}

Some plants that are rich in bioactive compounds and have the potential as phytobiotics in livestock such as Morinda citrifolia and Arthrospira platensis. Morinda citrifolia contains nutritional values such as minerals, vitamin, carbohydrates, and other nutrients which directly or indirectly help in metabolizing nutrients and good for cell and tissue growth (Abou Assi et al. 2017). Broilers fed fresh Morinda citrifolia juice $(1.5 \mathrm{ml} / \mathrm{head} /$ day $)$ showed better production performance on body weight gain, feed conversion and 
feed efficiency (Sunder et al 2011). The use of 5\% Morinda citrifolia extract in feed showed better body weight gain, growth, and performance of egg production in quails (Sunder et al. 2015).

Arthrospira platensis contain 60-70\% digestible protein with all essential amino acids, unsaturated fatty acids such as $\mathrm{V}$-linolenic acid, vitamins especially vitamin B12 and provitamin A and mineral especially iron and various photosynthetic pigments(Hosseini et al. 2013). The bioactive components of Arthrospira platensis include phycocyanin, $\beta$-carotene, $\mathrm{V}$-linolenic acid and phenolic compounds that make Arthrospira platensis has antioxidant, antimicrobial and immunestimulant properties, thus avoiding various diseases (Sudha et al 2011). Gružauskas et al. (2004) reported that Arthrospira platensis improved absorption of minerals and optimize nutrient digestion processes. Feeding Arthrospira platensis containing diets may increase the lactobacillus population and enhance the absorbability of dietary vitamins (Mariey et al. 2012). Antimicrobial activity in Morinda citrifolia as a feed additive is expected to improve the condition of microflora in the digestive system of poultry, especially in the small intestine. Good microflora conditions in the small intestine improve the absorption of feed substances so that feed digestibility and production performance improved. The antioxidant activity of Arthrospira platensis is expected to reduce or prevent damage by the oxidation process in quality poultry products. It is necessary to study effect of Morinda citrifolia and Arthrospira platensis in feed on productivity of broiler ducks which includes feed consumption, body weight gain, feed conversion and carcass quality like carcass percentage, abdominal fat, and internal organ weight.

\section{MATERIALS AND METHODS}

\section{Birds and dietary treatments}

One hundred sixty-eight hybrid broiler ducks with an initial body weight of $463 \pm 29.38 \mathrm{~g}$ were used in this study. The ducks were obtained from a local breeder. Completely randomized design with 7 treatments and 4 replications, 6 ducks per replication was arranged for this study. Treatments were $\mathrm{T} 0=$ basal diet, $\mathrm{T} 1=\mathrm{T} 0+$ $0.2 \%$ Morinda citrifolia powder (MP), T2 $=\mathrm{T} 0+0.5 \%$ Arthrospira platensis powder (AP), T3 $=\mathrm{T} 0+0.2 \% \mathrm{MP}$ $+0.5 \% \mathrm{AP}, \mathrm{T} 4=\mathrm{T} 0+0.4 \% \mathrm{MP}+0.5 \% \mathrm{AP}, \mathrm{T} 5=\mathrm{T} 0+$ $0.2 \% \mathrm{MP}+1 \% \mathrm{AP}, \mathrm{T} 6=\mathrm{T} 0+0.4 \% \mathrm{MP}+1 \% \mathrm{AP}$. The Morinda citrifolia and Arthrospira platensis powder addition were in the percentage of total diet basis. Composition and nutritional content of the basal diet are presented in Table 1.

\section{Experimental bird management}

This research was started with the preparation of Morinda citrifolia powder, Arthrospira platensis powder, diet, cage, and its equipment. Morinda citrifolia powder was obtained from Materia Medica (Batu, East Java, Indonesia). Arthrospira platensis was obtained from PT. Neoalga Indonesia Makmur (Sukoharjo, Central Java, Indonesia). The hybrid ducks from a local breeder were offered dietary treatments from one day to 42 days old. The birds from 1 to 14 days old were kept in litter cage, and they were moved and kept in the colony cages. Feeds and water were provided ad libitum throughout the study period. The experiment was conducted according to the standard procedures of rearing and treating farm animals as stated in the law of the Republic of Indonesia, number 18, 2009, concerning animal husbandry and health. Bodyweight and feed intake were measured weekly. The feed conversion ratio was determined as the feed intake per weight gain. At day 42, a total of 28 ducks were slaughtered, de-feathered, and eviscerated. The internal organs were immediately taken out and weighed. The following parameters were evaluated (in $\%$, in relation to live body weight and weight of eviscerated carcass without neck): eviscerated carcass without neck, head, and neck, quarter anterior of carcass, quarter posterior of carcass, wings with skin, breast and leg with skin, abdominal fat and visceral organ (heart, liver, gizzard, spleen, and giblet).

\section{Statistical analysis}

Data were analyzed based on a Completely Randomized Design by ANOVA. Significant differences among treatment groups were further analyzed using Duncan's multiple-range test. A significant level of $\mathrm{p}<0.05$ was implemented.

\section{RESULTS AND DISCUSSION}

\section{Performance}

Effect of dietary Morinda citrifolia and its combination with Arthrospira platensis powder on performance of broiler ducks are presented in Table 2 . The result showed that the treatments did not affect $(\mathrm{P}>0.05)$ feed intake. This may be due to iso-calorie and iso-nitrogenous dietary treatments used in this study which led to the same feed intake. Several previous studies also noted that Morinda citrifolia powder and Arthrospira platensis powder had no effect on feed intake in broiler chicken (Abd El-Hady \& El-Ghalid. 2018); (Mirzaie et al. 2018). 
Table 1. The composition and nutritional content of basal diet

\begin{tabular}{|c|c|}
\hline Ingredients & Amount \\
\hline Maize, $(\%$ as fed $)$ & 56.15 \\
\hline Soybean meal, (\% as fed) & 22.80 \\
\hline Meat Bone Meal, ( $\%$ as fed) & 7.20 \\
\hline Polished rice, $(\%$ as fed $)$ & 7.10 \\
\hline Lime Stone, $(\%$ as fed $)$ & 3.80 \\
\hline Palm Oil, (\% as fed) & 2.00 \\
\hline Premix, (\% as fed) & 0.50 \\
\hline Dicalcium Phosphate, (\% as fed) & 0.27 \\
\hline Salt, (\% as fed) & 0.18 \\
\hline \multicolumn{2}{|c|}{ Analyzed composition, \% of DM\#1: } \\
\hline Gross Energy, (cal/g) & 3428 \\
\hline Crude Protein, $(\%)$ & 18.69 \\
\hline Crude Fat, $(\%)$ & 2.53 \\
\hline Fiber, $(\%)$ & 1.31 \\
\hline Ash, $(\%)$ & 11.11 \\
\hline Calcium, $(\%)$ & 4.73 \\
\hline Phosphorus, $(\%)$ & 0.76 \\
\hline
\end{tabular}

A number of studies have revealed the consistent benefits of Arthrospira platensis on the growth performance of broiler chickens. Kaoud (2012) and (Jamil et al. 2015) reported that the addition of Arthrospira platensis powder to the diet improves weight gain and decreased feed conversion of broiler chickens. Based on these published data the author inferred the dietary Arthospira platensis on broiler ducks. The present results showed that the treatments did not give significant $(\mathrm{P}>0.05)$ effect on body weight, weight gain, and feed conversion ratio. This finding was similar to that of Mirzaie et al. (2018), which reported that supplementation of $1 \%$ Arthrospira platensis did not affect performance characteristics in broilers chickens. Sugiharto et al., (2018) reported that the period during which $S$. platensis was supplemented in broiler feed did not affect the growth performance of broilers. Irrespective of feeding duration, dietary supplementation with $1 \%$ of S. platensis resulted in a corresponding effect on growth performance when compared to feeding zinc bacitracin as a growth promoter to broiler. Abd El-Hady \& El-Ghalid (2018) reported that $S$. platensis supplementation to broiler diet improved feed conversion ratio. The improvement of FCR as a result of $S$. platensis supplementation could be attributed to the increase in body weight accompanied with no effect in feed intake.

\section{Carcass quality}

Data on comparison of the treatments of dietary Morinda citrifolia and Arthrospira platensis powder on quality of boiler duck carcasses are shown in Table 3. There were no significant $(p>0.05)$ different values of variables affected by treatments. This is in agreement with previous findings (Sugiharto et al. 2018) which also reported that there was no effect of dietary Arthrospira platensis on carcass traits of broilers chicks observed for 35 days. Several studies reported that feeding A. platensis increased carcass percentage of broiler chicks (Koud, 2012, Mariey et al. 2014) and Japanese quail (Jamil et al., 2015). The precise reason for these different results is not known, but the relatively similar final bodyweight may result in a similar carcass percentage of broiler among the treatment groups in the present study. This inference was supported by Mariey, et al. (2014) who suggested that carcass weight was in parallel with the live body weight of broilers. That is, the increased carcass weight 
Table 2. Effect of feeding Morinda citrifolia and Arthrospira platensis powder on performance production of broiler ducks

\begin{tabular}{|c|c|c|c|c|c|c|c|c|c|}
\hline \multirow{2}{*}{ Variables } & \multicolumn{7}{|c|}{ Treatments } & \multirow{2}{*}{ SEM } & \multirow{2}{*}{$p$} \\
\hline & T0 & $\mathrm{T} 1$ & $\mathrm{~T} 2$ & $\mathrm{~T} 3$ & $\mathrm{~T} 4$ & T5 & T6 & & \\
\hline Feed intake (g/bird) & 3231 & 3071 & 3221 & 3148 & 3127 & 3223 & 2947 & 41.00 & 0.52 \\
\hline Live body weight (g/bird) & 1429 & 1346 & 1315 & 1404 & 1390 & 1470 & 1397 & 21.95 & 0.62 \\
\hline Weight gain (g/bird) & 982 & 899 & 854 & 920 & 936 & 984 & 936 & 19.30 & 0.60 \\
\hline Feed Conversion Ratio & 3.29 & 3.42 & 3.77 & 3.42 & 3.34 & 3.27 & 3.15 & 0.07 & 0.38 \\
\hline
\end{tabular}

${ }^{1)} \mathrm{T} 0=$ basal diet, $\mathrm{T} 1=\mathrm{T} 0+0.2 \%$ Morinda citrifolia powder (MP), $\mathrm{T} 2=\mathrm{T} 0+0.5 \%$ Arthrospira platensis powder (AP), $\mathrm{T} 3=\mathrm{T} 0+0.2 \% \mathrm{MP}+$ $0.5 \% \mathrm{AP}, \mathrm{T} 4=\mathrm{T} 0+0.4 \% \mathrm{MP}+0.5 \% \mathrm{AP}, \mathrm{T} 5=\mathrm{T} 0+0.2 \% \mathrm{MP}+1 \% \mathrm{AP}, \mathrm{T} 6=\mathrm{T} 0+0.4 \% \mathrm{MP}+1 \% \mathrm{AP}$

Table 3. Effect of feeding Morinda citrifolia and Arthrospira platensis powder on quality of broiler duck carcasses.

\begin{tabular}{|c|c|c|c|c|c|c|c|c|c|}
\hline \multirow{2}{*}{ Variable } & \multicolumn{7}{|c|}{ Treatments } & \multirow{2}{*}{ SEM } & \multirow{2}{*}{$p$} \\
\hline & T0 & $\mathrm{T} 1$ & $\mathrm{~T} 2$ & $\mathrm{~T} 3$ & $\mathrm{~T} 4$ & $\mathrm{~T} 5$ & T6 & & \\
\hline Eviscerated carcass (g) & 1028 & 860 & 893 & 1001 & 919 & 1115 & 948 & 24.94 & 0.07 \\
\hline Dressing (\%) & 60.51 & 59.11 & 58.96 & 60.57 & 57.37 & 62.13 & 60.32 & 0.70 & 0.72 \\
\hline \multicolumn{10}{|l|}{ As $\%$ of dressed carcass } \\
\hline Quarter anterior (\%) & 27.74 & 26.69 & 27.23 & 27.20 & 27.39 & 27.35 & 27.47 & 0.22 & 0.17 \\
\hline Quarter posterior (\%) & 21.94 & 22.75 & 22.36 & 22.74 & 22.16 & 22.16 & 22.13 & 0.20 & 0.20 \\
\hline Breast $(\%)$ & 12.00 & 10.73 & 9.99 & 13.75 & 12.14 & 10.80 & 9.40 & 0.58 & 0.82 \\
\hline Thigh (\%) & 10.32 & 11.04 & 11.00 & 11.29 & 11.14 & 10.66 & 12.00 & 0.35 & 0.96 \\
\hline Wing (\%) & 7.66 & 7.82 & 7.34 & 6.43 & 6.92 & 6.89 & 7.31 & 0.15 & 0.14 \\
\hline Head and neck (\%) & 17.09 & 18.40 & 18.12 & 16.52 & 18.12 & 16.15 & 16.97 & 0.42 & 0.77 \\
\hline
\end{tabular}

${ }^{1)} \mathrm{T} 0=$ basal diet, $\mathrm{T} 1=\mathrm{T} 0+0.2 \%$ Morinda citrifolia powder $(\mathrm{MP}), \mathrm{T} 2=\mathrm{T} 0+0.5 \%$ Arthrospira platensis powder $(\mathrm{AP}), \mathrm{T} 3=\mathrm{T} 0+0.2 \% \mathrm{MP}+$ $0.5 \% \mathrm{AP}, \mathrm{T} 4=\mathrm{T} 0+0.4 \% \mathrm{MP}+0.5 \% \mathrm{AP}, \mathrm{T} 5=\mathrm{T} 0+0.2 \% \mathrm{MP}+1 \% \mathrm{AP}, \mathrm{T} 6=\mathrm{T} 0+0.4 \% \mathrm{MP}+1 \% \mathrm{AP}$

Table 4. Effect of feeding Morinda citrifolia and Arthrospira platensis powder on visceral organ of broiler ducks

\begin{tabular}{|c|c|c|c|c|c|c|c|c|c|}
\hline \multirow{2}{*}{ Item (\% live $\mathrm{BW}$ ) } & \multicolumn{7}{|c|}{ Treatments } & \multirow{2}{*}{ SEM } & \multirow{2}{*}{$p$} \\
\hline & T0 & $\mathrm{T} 1$ & $\mathrm{~T} 2$ & $\mathrm{~T} 3$ & $\mathrm{~T} 4$ & T5 & T6 & & \\
\hline Liver & 2.99 & 2.59 & 3.02 & 2.85 & 3.46 & 2.45 & 2.56 & 0.13 & 0.32 \\
\hline Gizzard & 3.14 & 3.70 & 3.07 & 3.21 & 3.24 & 3.07 & 3.12 & 0.08 & 0.52 \\
\hline Heart & 0.47 & 0.55 & 0.57 & 0.50 & 0.51 & 0.54 & 0.60 & 0.01 & 0.62 \\
\hline Spleen & 0.06 & 0.07 & 0.13 & 0.06 & 0.07 & 0.08 & 0.09 & 0.005 & 0.70 \\
\hline Giblet & 6.60 & 6.84 & 6.66 & 6.56 & 7.22 & 6.06 & 6.27 & 0.14 & 0.84 \\
\hline Abdominal fat & 1.36 & 0.70 & 0.95 & 1.73 & 1.15 & 1.24 & 0.90 & 0.12 & 0.26 \\
\hline
\end{tabular}

${ }^{1)} \mathrm{T} 0=$ basal diet, $\mathrm{T} 1=\mathrm{T} 0+0.2 \%$ Morinda citrifolia powder (MP), $\mathrm{T} 2=\mathrm{T} 0+0.5 \%$ Arthrospira platensis powder $(\mathrm{AP}), \mathrm{T} 3=\mathrm{T} 0+0.2 \% \mathrm{MP}+$ $0.5 \% \mathrm{AP}, \mathrm{T} 4=\mathrm{T} 0+0.4 \% \mathrm{MP}+0.5 \% \mathrm{AP}, \mathrm{T} 5=\mathrm{T} 0+0.2 \% \mathrm{MP}+1 \% \mathrm{AP}, \mathrm{T} 6=\mathrm{T} 0+0.4 \% \mathrm{MP}+1 \% \mathrm{AP}$

and total edible part were attributed to the final live bodyweight of broilers and vice versa

\section{Visceral organs}

Data describing the effect of dietary Morinda citrifolia and Arthrospira platensis powder on visceral organs of broiler ducks are summarized in Table 4. No significant different effects $(p>0.05)$ were found among treatments on liver, gizzard, heart, spleen, giblet and abdominal fat of broiler ducks. Nurhayati (2010) reported that using Morinda citrifolia powder in the ratio up to 10 percent did not significantly affect internal organ of broiler chickens. This is in agreement 
with (Sugiharto et al. 2018) that feeding of Arthrospira platensis $(1 \%)$ had no significant effect on internal organ of broiler chicks for 35 days. Total organ weight was found to be lower in bird fed with antibiotics as well as $0.05 \%$ Moringa fruit powder. A significant effect of herbal dietary treatment was not observed on subcutaneous fat content (neck, breast, and leg) of broiler carcass and on abdominal fat content (heart and vent) except the fat around gizzard (David et al. 2012).

\section{CONCLUSION}

The finding of the present study suggests that the dietary of Morinda citrifolia and Arthrospira platensis powder did not significantly improve performance and quality of broiler ducks carcasses.

\section{ACKNOWLEDGEMENT}

The study was financially supported by the Ministry of Research, Technology, and Higher Education, Indonesia.

\section{REFERENCES}

Abd El-Hady AM, El-Ghalid OAH. 2018. Spirulina platensis Algae (SPA): A novel poultry feed additive Effect of SPA supplementation in broiler chicken diets on productive performance, lipid profile and calciumphosphorus metabolism. VI Mediterranean Poultry Summit, World's Poult Sci J. 74:1-7.

Abou Assi R, Darwis Y, Abdulbaqi IM, khan AA, Vuanghao L, Laghari MH. 2017. Morinda citrifolia (Noni): A comprehensive review on its industrial uses, pharmacological activities, and clinical trials. Arabian J Chemist. 10:691-707.

David Ls, J.K Vidanarachchi, K. Samarasinghe, H.W. Cyriland and C.M.B Dematawewa. 2012. Effects of Moringa based feed Additives on the Growth Performance and Carcass Quality of Broiler Chiken. Trop Agric Res. 24 : 12-20.

Gružauskas R, Lekavicius R, Raceviciut-Stupelien R, Šašyt VT, Švirmickas GJ. 2004. Višiuk broileriu virškinimo procesu optimizavimas simbiotiniais preparatais.
Veterinarija ir Zootechnika, 28(50): 51-56.

Hosseini SM, Khosravi-Darani K, Mozafari MR. 2013. Nutritional and medical applications of spirulina microalgae. Mini reviews in medicinal chemistry. 13:1231-1237.

Jamil ABMR, Akanda MR, Rahman MM, Hossain MA, Islam MS. 2015. Prebiotic competence of spirulina on the production performance of broiler chickens. J Advd Vet Anim Res. 2:304-309.

Kaoud AH. 2012. Effect of Spirulina platensis as a dietary supplement on broiler performance in comparison with prebiotics. SJAR. 1: 44-48.

Mariey YA, Samak H., Ibrahem M. 2012. Effect of using spirulina platensis algae as afeed additive for poulrty diets: 1-productive and reproductive performances of local laying hens. Egypt Poult Sci. 32:201-215.

Mariey YA, Samak HR, Abou-Khashba HA, Sayed MAM, Abou-Zeid AE. 2014. Effect of using Spirulina Platensis algae as feed additives for poultry diets: 2-Productive performance of broiler. Egypt Poult Sci. 34:245-258.

Mirzaie S, Zirak-Khattab F, Hosseini SA, Donyaei-Darian H. 2018. Effects of dietary Spirulina on antioxidant status, lipid profile, immune response and performance characteristics of broiler chickens reared under high ambient temperature. AJAS. 31:556-563.

Nurhayati. 2010. Effect of noni fruit powder on digestive organs weight of broiler chickens. Agripet 10: 40-44.

Sudha SS, R Karthic, J Rengaramanujam, Athulya. 2011. Antimicrobial activity of Spirulina platensis and Aphanothece sp. on selected clinical bacterial isolates and its Antioxidant activity. South As J Biol Sci. 1: 8789.

Sugiharto S, Yudiarti T, Isroli I, Widiastuti E. 2018. Effect of feeding duration of Spirulina platensis on growth performance, haematological parameters, intestinal microbial population and carcass traits of broiler chicks. SASAS. 48:98-107.

Sunder J, Kundu A, Singh DR, Jeyakumar S, Srivastava RC. 2011. Effect of feeding of Morinda citrifolia fruit juice on growth, production and immune response in Nicobari fowl. Indian J Anim Sci 81: 68-71.

Sunder J, Tamilvanan S, Kundu A. 2015. Efficacy of feeding of Morinda citrifolia fruit juice and Lactobacillus acidophilus in broiler. AJAVA. 10:352-359. 